\title{
PMSM Control using the 3DSVPWM to Decrease Motor Torque Ripple and Motor Current THD with a New Model
}

\author{
Ali Saygin ${ }^{1}$, Ahmet Aksöz ${ }^{2 *}$ \\ ${ }^{1}$ Gazi University/ Electrical and Electronics Engineering Department, Ankara, TURKEY (ORCID: 0000-0003-1800-9655) \\ 2 Cumhuriyet University/ Mechatronics Engineering Department, Sivas, TURKEY (ORCID: 0000-0002-2563-1218)
}

(First received 5 February 2019 and in final form 6 March 2019)

(DOI: 10.31590/ejosat.522845)

ATIF/REFERENCE: Saygin, A. \& Aksöz, A. (2019). PMSM Control using the 3DSVPWM to Decrease Motor Torque Ripple and Motor Current THD with a New Model. European Journal of Science and Technology, (15), 327-332.

\begin{abstract}
In this paper, a new model for a PMSM (permanent magnet synchronous motor) driver is proposed. The proposed model is envisioned as a better modulating drive current waveform. In the proposed system the modulating drive motor current waveform is more similar to ideal sinusoidal waveform. Advanced IGBTs and snubber circuits can be employed in the design of the driver to obtain high performance with a simultaneous reduction in THD (total harmonic distortion) and torque ripple of the motor. The proposed concept offers a significant decreasing for driver harmonics compared to classical SVPWM used. The inverter can be operated in 3-phase and $20 \mathrm{kHz}$ switching frequency. A PMSM motor is operated at $3 \mathrm{~kW}$ and $48 \mathrm{~V}$ with the proposed model is evaluated via simulation with a corresponding SVPWM (space vector pulse width modulation) method. Results of torque ripple and THD of the motor currents on the model are discussed.
\end{abstract}

\section{Yeni Bir Modelle Motor Tork Dalgalanmalarını ve Motor Akımının Toplam Harmonik Bozuntusunu Azaltmak için 3DSVPWM Kullanarak PMSM Kontrolü}

Öz

Bu çalışmada, bir SMSM (sabit mıknatıslı senkron motor) sürücüsü için yeni bir model önerilmiştir. Önerilen model, daha iyi modüle edici bir tahrik akımı dalga biçimi olarak öngörülmüştür. Önerilen sistemde, modülasyonlu tahrik motor akımı dalga formu ideal sinüzoidal dalga formuna daha benzerdir. THB (toplam harmonik bozulma) ve tork dalgalanmasında azalma ile yüksek performans elde etmek maksadıyla sürücünün tasarımında gelişmiş IGBT'ler ve sönümleme devreleri kullanılabilir. Önerilen konsept, kullanılan klasik SVPWM'ye kıyasla sürücü harmonikleri için önemli bir düşüş sunuyor. Evirici, 3 faz ve $20 \mathrm{kHz}$ anahtarlama frekansında çalıştırılabilir. Bir PMSM motoru, önerilen model ile $3 \mathrm{~kW}$ ve $48 \mathrm{~V}$ 'da çalıştırılır ve bir UVDGM (uzay vektörü darbe genişliği modülasyonu) metodu ile simülasyon yoluyla değerlendirilir. Modeldeki motor akımlarının tork dalgalanması ve THB sonuçları tartışılmıştır.

Anahtar Kelimeler: Motor Torkunda Dalgalanmalar, SMSM, UVDGM, THB.

\footnotetext{
${ }^{*}$ Corresponding Author: Sivas Cumhuriyet Üniversitesi, Teknooji Fakültesi, Mekatronik Mühendisliği Bölümü, Sivas, Türkiye, ORCID: 0000-00022563-1218, aaksoz@cumhuriyet.edu.tr
} 


\section{Introduction}

Inverter design is very important for stable, compact and technologic motor drivers. Designed inverter must be overcome undesired effect of system due to nonlinear loads [1-3]. In order to get the better driver, the better PWM must be generated [1-6]. Generated PWM signals supply with desired voltage waveform in the inverter output. Moreover, better PWM signals can be achieved thanks to a better control approach. Therefore, the control strategy must be decided very well [7-11]. Although a PMSM design cannot be enough to the desired torque ripple and the desired motor current for the desired harmonics, it can be achieved to desired results by using the control strategy and PWM techniques.

This paper investigates the torque ripple and THD of motor currents issue of PMSM. Thanks to 2 cases, better results are found for these issues. Case 1 is composed of classical SVPWM and field oriented control (FOC) method and Case 2 consist of the 3DSVPWM and FOC. After the simulation results, the torque ripples and motor currents are discussed. In addition, the driver of this study is given in Fig. 1. Here, 400/50V autotransformer, a diode rectifier, 2 parallel big capacitor, a $3 \mathrm{~kW}$ inverter, a sensor card and FOC method are given below.

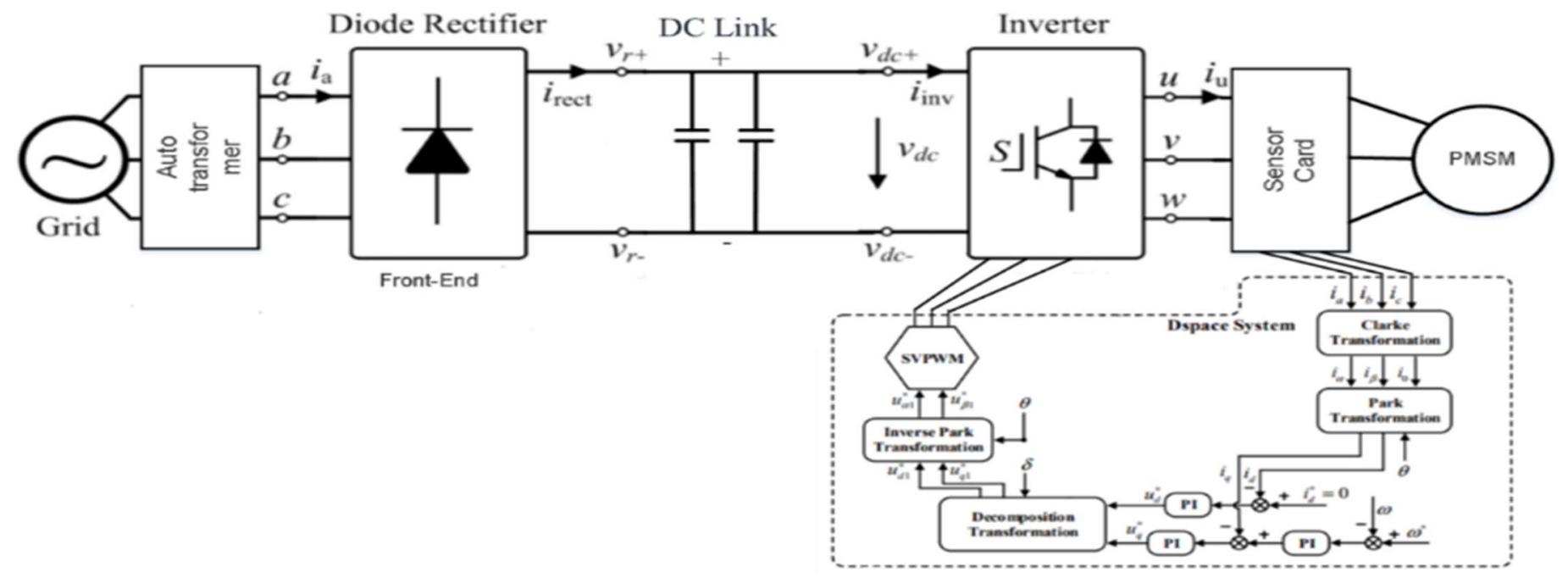

Figure 1. Driver Block Diagram.

In this paper, five sections consist of this study. In Section II, the PMSM model is described. The 3DSVPWM is explained in Section III. Then, simulated 2 cases are investigated and simulation results are discussed. Lastly, the paper is summarized in conclusion section.

\section{PMSM MODEL}

The mathematical equations of the modelled PMSM are given in the dq reference frame as,

$$
\begin{aligned}
& {\left[\begin{array}{c}
v_{s d} \\
v_{s q}
\end{array}\right]=\left[\begin{array}{cc}
R+s L_{s d} & -\omega_{r} L_{s q} \\
\omega_{r} L_{s d} & R+s L_{s q}
\end{array}\right]\left[\begin{array}{c}
i_{s d} \\
i_{s q}
\end{array}\right]+\left[\begin{array}{c}
0 \\
\omega_{r} \lambda
\end{array}\right]} \\
& T_{e}=\frac{3}{2} P\left(\lambda i_{s q}+\left(L_{s d}-L_{s q}\right) i_{s d} i_{s q}\right)
\end{aligned}
$$

where, id is presumed to 0 , it can be expressed that

$$
\begin{aligned}
& V_{s d}=-\omega_{r} L_{s q} i_{s q} \\
& V_{s q}=R i_{s q}+s L_{s q} i_{s q}+\omega_{r} \lambda
\end{aligned}
$$

All parameters of the PMSM is given in Table 1. 
Table 1. Parameter of the PMSM

\begin{tabular}{|l|l|}
\hline Parameter & Describtion \\
\hline $\mathrm{R}$ & stator resistor \\
\hline$\lambda$ & flux \\
\hline $\mathrm{P}$ & number of pole pairs \\
\hline Lsd, Lsq & stator inductances in the dq-frame \\
\hline $\mathrm{Te}$ & electrical torque \\
\hline$\omega \mathrm{r}$ & rotor speed \\
\hline vsd, vsq & stator voltages \\
\hline isd, isq & stator currents \\
\hline
\end{tabular}

\section{3DSVPWM}

This proposed modulation technique supplies is a three phased and balanced inverter. In addition, the relationship between the A, $\mathrm{B}$ and $\mathrm{C}$ voltages are given in Eq. 5.

$$
V_{A 0}(t)+V_{B 0}(t)+V_{C 0}(t)=0
$$

These voltages can be expressed in $\alpha-\beta$ planes.

$$
\vec{V}(t)=V_{\alpha}(t)+j V_{\beta}(t)
$$

$$
\left[\begin{array}{l}
\mathrm{V}_{\alpha}(\mathrm{t}) \\
\mathrm{V}_{\beta}(\mathrm{t})
\end{array}\right]=\frac{2}{3}\left[\begin{array}{ccc}
1 & \frac{1}{2} & \frac{1}{2} \\
0 & \frac{\sqrt{3}}{2} & -\frac{\sqrt{3}}{2}
\end{array}\right]\left[\begin{array}{c}
\mathrm{V}_{\mathrm{A} 0}(\mathrm{t}) \\
\mathrm{V}_{\mathrm{B} 0}(\mathrm{t}) \\
\mathrm{V}_{\mathrm{C} 0}(\mathrm{t})
\end{array}\right]
$$$$
\vec{V}(t)=\frac{2}{3}\left(V_{A 0}(t) e^{j 0}+V_{B 0}(t) e^{j 2 \pi / 3}+V_{C 0}(t) e^{j 4 \pi / 3}\right)
$$

\begin{tabular}{|c|c|c|c|c|c|c|}
\hline $\begin{array}{l}\vec{V} 0 \\
{\left[\begin{array}{lll}00 & 00 & 00\end{array}\right]} \\
{\left[\begin{array}{lll}00 & 00 & 11\end{array}\right]} \\
{\left[\begin{array}{lll}00 & 11 & 00\end{array}\right]} \\
{\left[\begin{array}{lll}00 & 11 & 11\end{array}\right]} \\
{\left[\begin{array}{lll}11 & 00 & 00\end{array}\right]} \\
{\left[\begin{array}{lll}11 & 00 & 11\end{array}\right]}\end{array}$ & 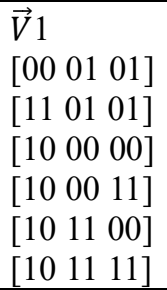 & $\begin{array}{l}\vec{V} 2 \\
{\left[\begin{array}{lll}10 & 10 & 00\end{array}\right]} \\
{\left[\begin{array}{lll}10 & 10 & 11\end{array}\right]} \\
{\left[\begin{array}{lll}00 & 00 & 01\end{array}\right]} \\
{\left[\begin{array}{lll}00 & 11 & 01\end{array}\right]} \\
{\left[\begin{array}{lll}11 & 00 & 01\end{array}\right]} \\
{\left[\begin{array}{lll}11 & 11 & 01\end{array}\right]}\end{array}$ & $\begin{array}{l}\vec{V} 3 \\
{\left[\begin{array}{lll}01 & 00 & 01\end{array}\right]} \\
{\left[\begin{array}{lll}01 & 11 & 01\end{array}\right]} \\
{\left[\begin{array}{lll}00 & 10 & 00\end{array}\right]} \\
{\left[\begin{array}{lll}00 & 10 & 11\end{array}\right]} \\
{\left[\begin{array}{lll}11 & 10 & 00\end{array}\right]} \\
{\left[\begin{array}{lll}1 & 10 & 11\end{array}\right]}\end{array}$ & $\begin{array}{l}\vec{V} 4 \\
{\left[\begin{array}{lll}00 & 10 & 10\end{array}\right]} \\
{\left[\begin{array}{lll}11 & 10 & 10\end{array}\right]} \\
{\left[\begin{array}{lll}01 & 00 & 00\end{array}\right]} \\
{\left[\begin{array}{lll}01 & 00 & 11\end{array}\right]} \\
{\left[\begin{array}{lll}0 & 11 & 00\end{array}\right]} \\
{\left[\begin{array}{lll}01 & 11 & 11\end{array}\right]}\end{array}$ & 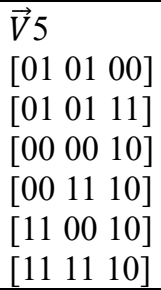 & $\begin{array}{l}\vec{V} 6 \\
{\left[\begin{array}{lll}10 & 00 & 10\end{array}\right]} \\
{\left[\begin{array}{lll}10 & 11 & 10\end{array}\right]} \\
{\left[\begin{array}{llll}00 & 01 & 00\end{array}\right]} \\
{\left[\begin{array}{lll}00 & 01 & 11\end{array}\right]} \\
{\left[\begin{array}{lll}11 & 01 & 00\end{array}\right]} \\
{\left[\begin{array}{lll}11 & 01 & 11\end{array}\right]}\end{array}$ \\
\hline $\begin{array}{l}{\left[\begin{array}{lll}11 & 11 & 00\end{array}\right]} \\
{\left[\begin{array}{llll}11 & 11 & 11\end{array}\right]} \\
{\left[\begin{array}{llll}0 & 0 & 0 & 01\end{array}\right]}\end{array}$ & $\begin{array}{l}\overrightarrow{\vec{V} 7} \\
{\left[\begin{array}{lll}10 & 0 & 0 \\
10 & 01\end{array}\right]} \\
{\left[\begin{array}{lll}10 & 11 & 01\end{array}\right]}\end{array}$ & $\begin{array}{l}\overrightarrow{\vec{V} 8} \\
{\left[\begin{array}{lll}00 & 10 & 01\end{array}\right]} \\
{\left[\begin{array}{lll}11 & 10 & 01\end{array}\right]}\end{array}$ & $\begin{array}{l}\overrightarrow{\vec{V}} 9 \\
{\left[\begin{array}{lll}01 & 10 & 00\end{array}\right]} \\
{\left[\begin{array}{lll}01 & 10 & 11\end{array}\right]}\end{array}$ & 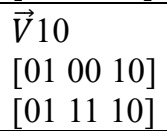 & 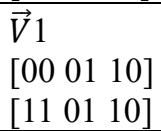 & $\begin{array}{l}\overrightarrow{\vec{V}} 12 \\
{\left[\begin{array}{lll}10 & 0 & 0\end{array}\right]} \\
{\left[\begin{array}{lll}10 & 01 & 11\end{array}\right]}\end{array}$ \\
\hline $\begin{array}{l}{\left[\begin{array}{lll}10 & 10 & 10\end{array}\right]} \\
\text { [S1S2S3S4S5S6 }] \\
\text { Switch on : } 1 \\
\text { Switch off: } 0\end{array}$ & $\begin{array}{l}\vec{V} 13 \\
{\left[\begin{array}{lll}10 & 01 & 01\end{array}\right]}\end{array}$ & $\begin{array}{l}\vec{V} 14 \\
{\left[\begin{array}{lll}10 & 10 & 01\end{array}\right]}\end{array}$ & $\begin{array}{l}\vec{V} 15 \\
{\left[\begin{array}{lll}01 & 10 & 01\end{array}\right]}\end{array}$ & $\begin{array}{l}\vec{V} 16 \\
{\left[\begin{array}{lll}01 & 10 & 10\end{array}\right]}\end{array}$ & $\begin{array}{l}\vec{V} 17 \\
{\left[\begin{array}{lll}01 & 01 & 10\end{array}\right]}\end{array}$ & $\begin{array}{l}\vec{V} 18 \\
{\left[\begin{array}{lll}10 & 01 & 10\end{array}\right]}\end{array}$ \\
\hline
\end{tabular}

Each vector switching status are given in Table 2. Here, 18 vectors are used in this proposed techniques.

Table 2. Each Vector Switching Status

\section{Simulation Results}

The designed cases give the torque ripple results and THD of motor currents results. Torque ripple on electrical torque in given in Table 3 . 
Table 3. Torque Ripple on Te.

\begin{tabular}{|l|l|l|l|}
\hline Models & Te $\mathbf{( N m )}$ & RMS(Nm) & Torque ripple (Nm) \\
\hline Case 1 & 4.060 & 3.615 & 0.445 \\
\hline Case 2 & 4.071 & 3.632 & 0.439 \\
\hline
\end{tabular}

In table 3, electrical torque of Case 1 is $4.060 \mathrm{Nm}$ and electrical torque of Case 2 is also $4.071 \mathrm{Nm}$. RMS values are respectively $3.615 \mathrm{Nm}$ and $3.632 \mathrm{Nm}$. However, torque ripple of Case 1 is $0.445 \mathrm{Nm}$ and torque ripple of Case 2 is $0.439 \mathrm{Nm}$. Electrical torque of two cases are illustrated in Fig 2.

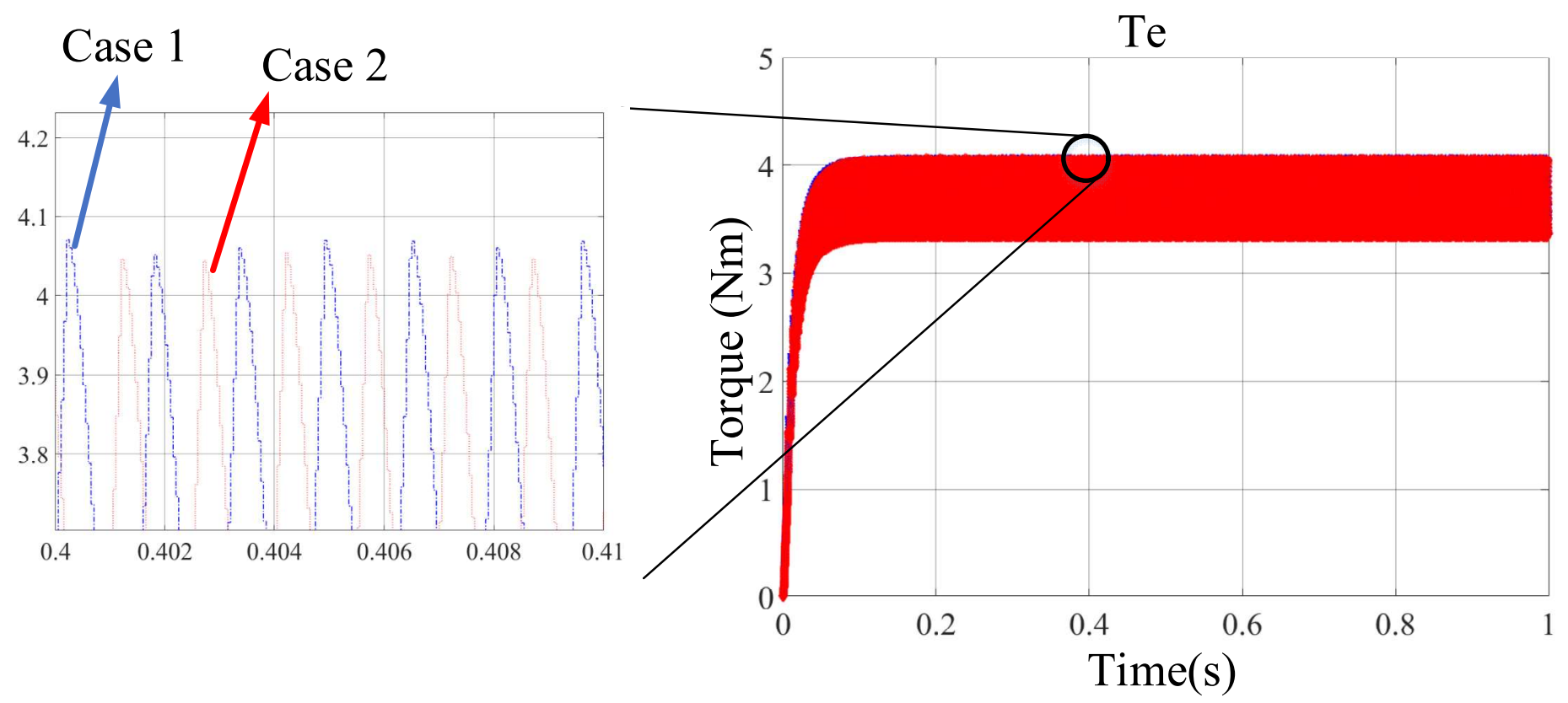

Figure 2. Electrical Torque of Two Cases

Motor currents of two cases are shown in Fig 3.

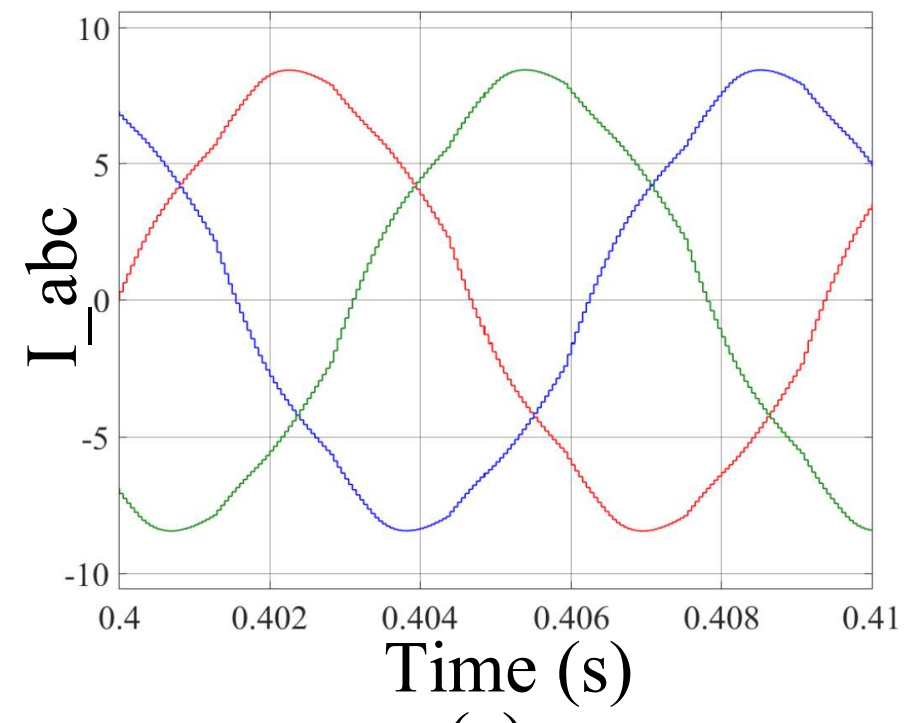

(a)

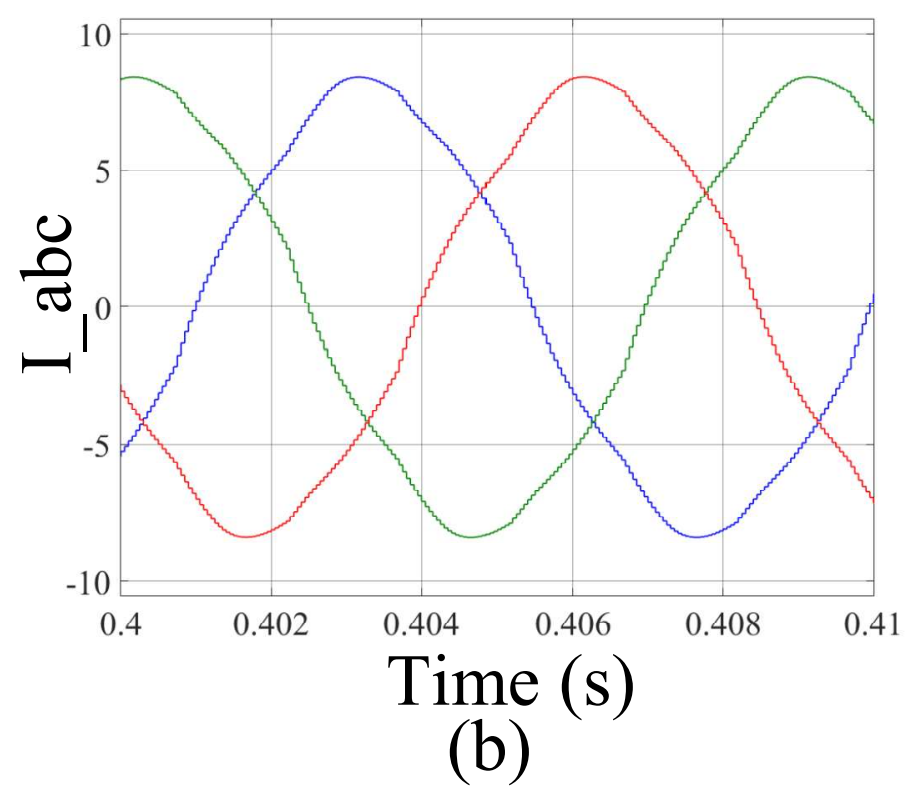

(b)

Figure 3. Motor Currents of Two Cases. ((a) is Case 1 and (b) is Case 2)

According to the Fig 3. THD of motor currents are expressed in Table 4. 
European Journal of Science and Technology

Table 4. THD of Motor Current

\begin{tabular}{|l|l|}
\hline Models & THD \\
\hline Case 1 & $41.65 \%$ \\
\hline Case 2 & $37.35 \%$ \\
\hline
\end{tabular}

Above THD of Case 1 is $41.65 \%$ and THD of Case 2 is $37.35 \%$. It is clearly seen that both torque ripple results and THD results of Case 2 is better than results of Case 1. Thus, it is mentioned that the 3DSVPWM has good effect on torque ripple and THD.

\section{Conclusion}

The proposed new model with the 3DSVPWM for a PMSM driver is expressed. The proposed model is envisioned as a better modulating drive current waveform. In order to obtain high performance thanks to the decreasing THDi and torque ripple of the motor, the classical SVPWM and the 3DSVPWM is applied in two cases. After the case results, it is precisely understood that the 3DSVPWM can be preferred in many PMSM driver study. Because it has very good effect on motor torque ripple and THD of motor currents.

\section{Acknowledgements}

The authors thank TUBITAK 2211-A (Grant number: 1649B031400107).

\section{References}


A. Saygin, A. Aksoz and E. N. Yilmaz, A different model of WECS connected to smart grid through matrix converter, 2016 4th International Istanbul Smart Grid Congress and Fair (ICSG), Istanbul (2016), pp. 1-5. DOI: 10.1109/SGCF.2016.7492419

A. Saygin, A.M. Rashid, Position control of a turret using LabVIEW, Acta Physica Polonica A (2017) 132 (3), pp. 970-973. DOI: 10.12693/APhysPolA.132.970

A. Saygin, A. Kerem, Speed control of an induction motor by 6-switched 3-level inverter, Open Physics, (2017) 15 (1), pp. $1072-$ 1076. DOI: 10.1515/phys-2017-0138

A. Saygin and A. Aksoz, Design optimization for minimizing cogging torque in Axial Flux Permanent Magnet machines, 2017 International Conference on Optimization of Electrical and Electronic Equipment (OPTIM) Brasov (2017), pp. 324-329. DOI: 10.1109/OPTIM.2017.7974991

E.N. Yilmaz, A. Aksoz and A. Saygin, Electr Eng (2018).DOI: 10.1007/s00202-018-0734-4

E. Can, H.H. Sayan, A novel SSPWM controlling inverter running nonlinear device, Electrical Engineering, (2018) 100 (1), pp. 39-46. DOI: $10.1007 / \mathrm{s} 00202-016-0480-4$

E. Can, H.H. Sayan, The increasing harmonic effects of SSPWM multilevel inverter controlling load currents investigated on modulation index, Tehnicki Vjesnik, (2017) 24 (2), pp. 397-404. DOI: 10.17559/TV-20151020134629

M.K. Döşoğlu, U. Güvenç, Y. Sönmez, C. Yılmaz, Enhancement of demagnetization control for low-voltage ride-through capability in DFIG-based wind farm, Electrical Engineering, (2018) 100 (2), pp. 491-498. DOI: 10.1007/s00202-017-0522-6

N.G. Adar, R. Kozan, Comparison between Real Time PID and 2-DOF PID Controller for 6-DOF Robot Arm, Acta Physica Polonica A (2016) pp 269. DOI:10.12693/APhysPolA.130.269

N.G. Adar, A. Egrisogut Tiryaki, R. Kozan, Real Time Visual Servoing of a 6-DOF Robotic Arm using Fuzzy-PID Controller, Acta Physica Polonica A (2015) pp B-348. DOI: 10.12693/APhysPolA.128.B-348

R. Kiliç, Determination of Imbalance Problem in Electric Motor and Centrifugal Pump by Vibration Analysis, Acta Physica Polonica A (2016) pp487. DOI:10.12693/APhysPolA.130.487

S. Altuntaş, H. Hapoğlu, S. Ertunç, M. Alpbaz, Experimental Self-Tuning Proportional Integral Derivative pH Control: Application to a Bioprocess, Acta Physica Polonica A (2017) pp 1006. DOI: 10.12693/APhysPolA.132.1006

Y. Sarikaya, H. Apaydin, Ş. Kıtış, A Hydrolysis System Design and Ana-lysis for Vehicles with Microprocessor Based and PWM Controlled Card, Acta Physica Polonica A (2015) pp B-211. DOI: 10.12693/APhysPolA.128.B-211 